\title{
AN ECOLINGUISTIC ANALYSIS OF THE USE OF METAPHOR TO ENHANCE THE VALUE OF PRODUCTS IN ADVERTISEMENTS
}

\section{Fasih Ahmed $^{*}$, Quratul Ain ${ }^{2}$, Shazia Akbar Ghilzai ${ }^{3}$}

${ }^{1 *}$ Assistant Professor, Department of Humanities, COMSATS University, Islamabad, Pakistan; ${ }^{2}$ Lecturer, Women University

Swabi, KP, Pakistan; ${ }^{3}$ Lecturer, Quaid-e-Azam University, Islamabad, Pakistan, and Ph.D., USPN Paris, France.

Email: ${ }^{1 *}$ fasih.ahmed@comsats.edu.pk, ${ }^{2}$ quratulainshah12@yahoo.com, ${ }^{3}$ sghilzai@qau.edu.pk

Article History: Received on $9^{\text {th }}$ April 2021, Revised on $20^{\text {th }}$ April 2021, Published on $1^{\text {st }}$ May 2021

\begin{abstract}
Purpose of the study: The study investigates metaphors in advertisements from the perspective of ecolinguistics. It focuses on the reasons for which the manufacturers use metaphors for the advertising of their products. It also aims to find the role of metaphor in arising feelings of the consumers towards the products.

Methodology: The data have been collected from the official website of four multinational companies named A, B, C, and D. Only thirteen advertisements are analyzed in this research. The selection is made based on the use of metaphor in the advertisements - theory of Conceptual metaphor by Lakoff and Johnson (2008) and Stibbe (2015)'s Model of ecolinguistic analysis guided the mode of the present research.
\end{abstract}

Main Findings: It is found that the manufacturers make use of metaphors to grab the attention of the audience towards the product through its sensual appeal. Moreover, the advertising agencies assign some other entity qualities through meta help in the positive evaluation of their products' value.

Applications of this study: Since the research analyzes metaphors in advertisements, it helps educate the common masses about metaphors and their impact on the customers' feelings. The affiliation of the advertised products with positive qualities or entities makes the product the right choice for the audience and enhances its value.

Novelty/Originality of this study: The study is novel because it investigates the reasons for using metaphors in advertisements and how it helps the manufacturers persuade consumers to buy their products. The use of metaphor enhances the value of the products. In contrast, the consumers overlook the product's importance and get the product's illusion as something bringing feelings of joy and pleasure to the consumers.

Keywords: Ecolinguistics, Metaphors, Advertisements, Product, Source Domain, Target Domain.

\section{INTRODUCTION}

The role of metaphor in language, cognition, and experiences is imperative (Thibodeau, Matlock, \& Flusberg, 2019). Metaphor has been defined, theorized, and applied by many scholars in many different ways (Caballero, 2003; CharterisBlack, 2009; Semino \& Demjén, 2016). There is a consensus that metaphor deals with the consideration of similarities between two different objects or processes so that one can be visualized, perceived, experienced, and talked about in terms of the other one. For example, "our lives as journeys, our minds as machines, our emotions as external forces, people as animals, inanimate objects as people"(Semino \& Demjén, 2016, p. 1). Through the use of such metaphors, the attributes of one object are given to another entity. Besides being a rhetorical device in the language system, metaphors are considered conceptual ones and play a vital role in shaping social realities (Jensen, 2006). An analogy may determine or guide future actions through the use of metaphor in the language system. It consequently makes two incongruent experiences parallel to one another (Musolff, 2012).

Advertisements play a vital role in the product's publicity and affect the consumers' psyche (Rai, 2013). It requires practical and appealing use of words or, in other words, the proper use of language in the right context (Burgers, Konijn, Steen, \& Iepsma, 2015). The listeners cannot avoid the effect since the advertisements have the authority to influence them. The companies or brands make use of such linguistic items, which enhance the value of their products. The present research has taken the advertisements of three multinational companies. It analyzed the metaphors used in these advertisements under the theoretical framework of Conceptual Metaphor Theory. Stibbe (2015)'s model of ecolinguistics analysis was adopted for analysis of the study. The research deals with the following research questions:

1. What are the reasons for the use of metaphors in advertisements?

2. How are metaphors used in advertisements to arouse the feelings of the consumers?

\section{LITERATURE REVIEW}

Ecolinguistics is a scientific discipline with a focus on the nature and function of language. It is a mode of organization of the living system (human society) and its role in the evolution of the brain, mind, and (self-) consciousness (Kravchenko, 
2016)." The prime focus is on the relationship between language and the cultural environment. This field of study is often called linguistic ecology, language ecology, and also green linguistics. Alexander and Stibbe (2014) define ecolinguistics as a field of study that discusses the impact of language use in survival that tries to link human beings, other species, and the physical or natural environment that is inclined to safeguard a sustainable relationship among humans and other species in an ecosystem. Bang and Trampe (2014) divide ecolinguistics into two paradigms, "On the one hand traditional linguistic methods applied contexts and discourse of ecological importance and on the other hand deeper reflections on the theories of language inspired by the holistic paradigm of ecology" (p. 83). Concerning ecology, ecolinguistics is also regarded as green discourse (Yuniawan, 2018).

Ecolinguistics further evolved as critical ecolinguistics. Critical ecolinguistics is a combination of language ecology and critical discourse analysis (Stibbe, 2014). Critical ecolinguistic investigates the ecological discourse and their philosophy that are pertinent to people and the environment. The use of lexical units in green speech affects the persons' thinking and is logically incorporated in the discourse, the authors, and readers (Nahak, Simpen, Yadnya, \& Satyawati, 2019). The researches in ecolinguistics suggest if green speech is positive, then their behaviors to the environment are productive. On the other hand, if green discourse is unhelpful and unfair, actions and thoughts concerning the environment may devastate (Alexander \& Stibbe, 2014; Döring, Penz, \& Trampe, 2008; Nahak et al., 2019).

Ecolinguistics also unveils the use of rhetorical devices such as metaphors for the sake of commercial discourses. In commercial addresses, metaphors play a crucial role in engaging the customers and persuading the audience to purchase a product (Nuzwaty, Setia, \& Zein, 2014). Metaphors have a persuasive function for this genre. They appeal to the senses, emotions, and evaluative judgment of the consumers by attributing positive qualities to the product through unique strategies (Fill \& Muhlhausler, 2006). The use of metaphor, humor, and language play is an indirect strategy to persuade the audience and achieve the desired effect (Stoyanova, 2021). Other than an attention-grabbing device, metaphors are used to associate the advertised product with some other entity, where the entity's qualities are applied to the advertised product. In critical cognitive discourse, the use of metaphor in the commercial advertisement is seen as a social act, which might appear in the text as practices assimilated or repudiated by the viewers. They may also propagate them in different social contexts (Mohammed, 2020; Qiushi, 2020). It can be shaping some aspects of reality, reproducing power relationships other stereotypes in society. Besides shaping reality, metaphor has the power to link cognition with the use of language in a social act (Ding, 2020). Thus, personification used as metaphor has an influential role as they present abstract ideas and objects such as corporations and their facilities, as human beings have some traits (Delbaere, McQuarrie, \& Phillips, 2011).

Personification is one of the rhetoric tools used in advertisements. Brands are made concrete through the use of metaphors as "BRANDA ARE LIVING ORGANISMS" and "BRANDS ARE PEOPLE"(Stibbe, 2015, p. 327). The brands are metaphorically presented as human beings, with a positive evaluation. Metaphors play a role in the companies' mission statement and logos that reflect their personalities (Kraljevic-Mujic, 2017). Grant (2012) reviews metaphorical and factual knowledge in cultural and biological diversity. Biodiversity and cultural diversity are made metaphorically parallel to one another, which somehow is believed to help in the development of intangible cultural heritage such as music and language. It is also observed that the success or failure to safeguard biodiversity will also affect protecting cultural heritage and vice versa. The paper reviews these issues and gives suggestions to policy-makers, government, and autonomous organizations, culture-bearers, and stakeholders, dealing with cultural diversity.

Consumers feel processed foods or items as an alternative to natural food or beverages, and they prefer to buy advertised products than natural ones (Ain, Ahmed, \& Nawaz, 2021; Hasyim, 2017). The consumers position themselves at a stage where the advertised products become their preference to gain a more healthy effect than the natural one (Kao \& Du, 2020). The environmental knowledge that consumers believe that a product is good for the environment without knowing how the product impacts the environment (Martin \& Simintiras, 1995). As a result, commercialism harms the environment (Chen, 2016; Damico, Baildon, \& Panos, 2020; Norton \& Hulme, 2019).

The above-mention studies provide information about ecolinguistics and the modus operandi of commercial advertisements. The studies also suggest that various literary devices are used for the sake of product promotion. Among these literary devices, metaphors are prominent. Hence, it implies a need for a practical approach for analyzing metaphors and finding out how they align with ecolinguistics ideals. The present study has investigated multinational companies' advertisements. It aimed to find out how metaphors are used in the advertisements to raise the consumers' feelings and look into the reasons. The manufacturers use metaphors in the advertising of their products.

\section{RESEARCH METHODOLOGY}

\section{Research Design}

The qualitative method has been selected for the current research. The data has been collected from the official websites of four multinational companies. 


\section{Research Model}

Stibbe (2015)'s ecolinguistic analysis model has been selected to dissect the advertisements' metaphors. "Ecolinguistics analyses language to reveal stories we live by judges those stories according to an ecosophy, and contributes to the search for new stories to live by (Stibbe, 2015, p. 183)." The selected framework seeks to reveal the stories present all around us and resist those 'stories-we-live-by' that are harmful to our planet. It is done through close examination of the language that people use because language provides clues to the existence and structure of the stories we live by. Stibbe (2015) identified eight different forms of narratives. For the current research, only one story, i.e., metaphor, has been selected. Metaphor is a distinct kind of framing, defined as "Metaphors use a frame from a specific, concrete and imaginable area of life to structure how a distinct area of life is conceptualized" (p. 64). The linguistic categories that help develop metaphors include the choice of lexis, entailment, hyponymy, and metonymy.

\section{Theoretical Framework}

The theory of conceptual theory has been selected to support the study's argument. Lakoff and Johnson (2008) proposed that metaphor is a stretch of language and affects cognition and helps the individuals understand ideas, speak, and rationalize others. Metaphors are explained in terms of conceptual mapping, in which correspondence is made between the source domain and target domain. The source domain is mapped onto the target domain and understood in terms of the source domain. The source domain is the traditional vehicle, which is less abstract, i.e., easily comprehendible or imaginable by the human mind, as compared to the target domain. The target domain is the traditional tenor. In the example, LOVE IS A JOURNEY, the source domain of journey, i.e., the concept of moving on a path to reach a destination, is applied to the idea of love. (Harnendaz, 2011)

Metaphor exists not only in the language system but also in the thought process (Hampe, 2017). The metaphors are used to talk about some facets of life and perceive them in a particular manner. These metaphors are referred to as conceptual metaphors because some conceptual frameworks of life are applied to imagine other life facets. It is elaborated with the example, "LIFE IS A JOURNEY" (p.16), in which the definition of life is determined by the metaphor used for it. Life is understood in terms of a journey where plans are made, some goals to achieve, preference of some paths over others to reach the destination, etc. By making such comparisons, life is perceived in terms of the conceptual metaphor, i.e., "LIFE IS A JOURNEY," which results in language usage of the journey for life. (Kovecses, 2017)

\section{Sample and Setting}

The data has been collected from the official website of four multinational companies. A total of 13 advertisements are selected based on relevancy to the concept of metaphor. In each of the companies, only those advertisements are chosen. Those carry clear examples of metaphors. The data selected is of four multinational companies, and their advertisements are designed for the consumers of Pakistan.

\section{ANALYSIS}

\section{Company A}

\section{Product 1(A)}

The metaphor embedded in product 1(A) discourse is that the milk "empowers women." It inspires a change in the mindset and lifestyle of women. The product is used as a behavioral process behavior and makes the women powerful to take charge of their lives and achieve their goals as clearly stated. "Inspiring a change in mindset and lifestyle... empowers women to take charge of their lives and move towards their goals". This metaphor underpins the story that the product is a powerful entity that changes women's psyche and lifestyle. These lines do not present it as a form of milk or drink instead of as an authorized body, which has the power to sanction authority to women and change their lives.

\section{Product 2(A)}

Metonymy has been used twice, where a partner's qualities, i.e., human beings, have been given to the product as "market leader" and "tea partner." The human quality of leadership is being assigned to the product. Similarly, the partner is the kind of person who is with the other person all the time. Here, the term partner is used metaphorically to denote the idea that this particular product is your partner when the reader has to make tea choices as in the text, "your go-to tea partner." It is implicitly substituting the company of human beings with this product.

Another instance of metaphor in the same advertisement is that the source frame of "ride" is mapped onto the target domain of dry milk. In the text, "we promise you a KHAAS sensorial ride that is sure to elevate your every tea moment." The ride frame brings the trip's schemata, journey, pleasure, and excitement to readers' minds. The same schemata are applied to the experience of tea made with this product. The metaphors used for the product can be called destructive metaphors. They are replacing human beings and other sources of enjoyment with milk, which implicitly promotes consumerism. 


\section{Product 3(A)}

There is an example of metonymy in the advertisement. The product is given human-like qualities, such as it "inspires you." It means that the effect gives inspiration for providing the best performance. "It supports your drive to succeed" implies that the milk provides support for the mission of success and "enables you to enjoy the true achievement." All these humanly attributes of inspiring, supporting for success, and enabling the celebration of success are given to the product. Through the use of metonymy, the product is presented with some goals carried out on human beings.

\section{Product 4(A)}

New is an adjective that has been converted into "NEWISM" by adding the suffix "ism" to it. The word 'ism' stands for a set of beliefs and values. The word NEWISM is not part of the English dictionary, rather a newly coined word. The drink/juice is made equivalent to NEWISM as in the advertisement, "It stands for the ideal of NEWISM which encourages young teenagers to bring 'newness' in everything they do." Here, it entails that those teenagers who consume the drink can bring creativity and innovation in whatever they do. In the starting line, teenagers of school, college, and university are targeted, bored of monotonous days and evenings. They want to bring some change and do something exciting, so the drink is offered as an ideal of NEWISM, which helps acquire these delights and pleasure of innovation. Here, the juice is mapped onto NEWISM. The metaphor of NEWISM, newness, and creativity are made equivalent to the product's consumption, which is an unnecessary increase in consumerism.

\section{Company B}

\section{Product 1(B)}

As in "juice brings you" and "will leave you feeling great," the product's active role denotes that the product is a person-an example of metonymy. The juice is presented as an actor, with some desires and goals, who make some actions on human beings and bring the flavors of mango and apple to them and make them feel good. Human beings can feel good in many other ways, such as spending good time with family, visiting friends, helping others, spending time with nature, taking care of different species, pursuing a hobby, or any other phenomena. It does not necessarily include purchasing or spending money. Here, feeling great (source frame) has been advertently mapped onto drinking the juice (target domain), promoting consumerism, and the metaphor can be labeled as a destructive metaphor.

\section{Company $\mathbf{C}$}

\section{Product 1(C)}

The advertisement starts with that the product "brings you pure natural goodness of butter." The butter is used metonymically that it is not the human beings who have extracted the butter from natural resources. Instead, the company itself has produced it. The product is presented as an actor and the consumer as passive beings. It hides the agency that the individuals may not be blamed for discomfort or inconvenience to the consumers in adverse effects or side effects.

\section{Product 2(C)}

The statement, "an appetizing drink which takes care of your daily dietary requirements," gives the drink the quality of living entities that care for human beings' nutritional value. It is an example of metonymy. It is not stated or written that the manufacturers have formulated it to take care of human's daily dietary requirements. Nutrition is already present in natural products, but the daily nutritional requirements are fulfilled by human beings that what products it consumes to meet those requirements. Here, these human characteristics are being assigned to the product in this discourse, assumed as a conscious entity who knows or knows humans' daily dietary requirements.

\section{Company D}

\section{Product 1(D)}

The source frame of "twist" is mapped onto the company's pomegranate juice's target domain. The pleasure and excitement of surprise are made equivalent to the liquid that the taste will surprise them if they consume the beverage.

\section{Product 2(D)}

A sleeping metaphor has been used that drinking this juice is doing a favor to yourself. The source frame of "favor" is mapped onto the target domain of "Mango Twist," which brings to the mind words like "kind," "gift," "sympathy," and "help." Through the use of the sleeping metaphor, these feelings are associated with Mango Twist by the readers.

\section{Product 3(D)}

The source domain of the journey is mapped onto drinking lychee drink. The journey is used as a metaphor for the flavor of 
lychee. The frame of the journey brings to mind going from one place to another or on a trip. It is a sleeping metaphor as stated in the advertisement, "the exotic flavor of Lychee, the famous summer fruit with looks to match and go on a flavor journey that's going to be hard to forget." Consumption of the drink is made equivalent to going on a flavor journey that is difficult to forget. The experience of a trip and the pleasure are mapped onto the product to develop the story. People can experience the joy of going on a journey by drinking. It can act as a catalyst for an increase in consumerism.

\section{Product 4(D)}

A vivid metaphor has been used, the sensual details in "Feel the gentle breeze in your hair and sand in your feet." This vivid description gives the readers the feel of being on a beach. Followed by a semicolon, it further states, "be transported to your Hawaiian retreat." Hawaii is a state in the United States of America that has many islands. Here the drink, which has the flavors of tropical fruits, is mapped onto the experience of being on Hawaii Island. The metaphor implies that drinking or enjoying the product is equivalent to the enjoyment or experience of being on Hawaii Island.

\section{Product 5(D)}

The metaphor of time is mapped onto the product. The frame of "good time" is applied to drinking this particular juice as in the advertisement, "Have a good time with the" juice. A good time can be defined as expressed differently. Every individual will associate different feelings, emotions, people events, experiences, and entities based on their experiences. Still, in the advertisement, a good time is related to the consumption of the product. Through the use of metaphor, the excessive purchase of the product is promoted covertly.

\section{Product 6(D)}

The source frame of the game is applied to the target domain of the juice. A game has the edge of a sport, having some rules to win the competition and win against opponents. Here, the company claims that presenting the best flavor of oranges is a game. In this game, the flavor presented by company D is strong and better than all others as in the advertisement, "When it comes to our oranges, our flavor game is strong." The metaphor implies that presenting the best flavor is a game. It can be called an ambivalent metaphor because every company will strive to provide the best flavor to its consumers through this story. On the other hand, it can lead to some adverse consequences; for flavors, some companies might add artificial flavors and chemicals to the juices to make the taste strong. The artificial flavors and chemicals can be hazardous for human health, especially for children, where these kinds of drinks are liked the most.

\section{DISCUSSION}

The present research investigated the use of metaphor in advertisement to identify the types of metaphors. For this purpose, multinational companies' publicity was the focus of the study - the product of four multinational companies selected for investigating metaphors and their importance. The study applied conceptual metaphor theory Lakoff and Johnson (2008) and followed Stibbe (2015)'s model of ecolinguistics.

The first question of the study is to determine the reasons for the benefit of metaphors in advertisements. Based on the data analysis, the metaphors have a persuasive effect on the language system (Lakoff \& Johnson, 2008). They appeal to the audience's senses and emotions, so they use them to grab the audience's attention towards their product (McQuarrie \& Phillips, 2005; Morgan \& Reichert, 1999). Secondly, metaphors apply the source domain features onto the target domain so that positive attributes of one entity or feeling are associated with the product, which persuades the readers to think positively about the products (DeRosia, 2008). The audience has a positive attitude towards those qualities such as women empowerment, inspiration for success, sensorial ride, and to be on an island (Forceville, 2000). These feelings are positively evaluated in the human mind (Coulter, Zaltman, \& Coulter, 2001).

For this reason, the manufacturers indirectly make the audience think simply about their products, too, through metaphors. The audience may feel good or excellent by spending time with loved ones, taking care of nature, helping humanity, or doing any other act, which may benefit fellow human beings, other species, and the planet in general. The association of such feelings and ideals with the consumption of products subsequently increases their products' purchase, thus strengthening their economy.

The second question of the research is how metaphors used in the advertisement create feelings for the audience. The products' consumers are attracted to the product through metaphors, which has a persuasive effect (Sopory \& Dillard, 2002). As metaphors have the quality that the attributes of one object are mapped onto the other, the same instances have been found in the selected companies' analysis (Freeman, 2000). The advertising agencies map the positive qualities of one thing or feeling to the products, which persuades them to think about the product as the companies want them to think (Liu et al., 2020). The analysis found that the products are associated with women empowerment, prosperous future, partner, ride, inspiration, feeling great, favor, Hawaii Island, journey, feeling good, and game. All these ideas, feelings, objects, and phenomena are positively evaluated in the language system. Making them equivalent to the products compels the readers to 
think that they can achieve these objectives by consuming a product. The brands use these metaphors to increase their products' purchase, but the consumers buy the product and start believing in the reality, which the brands narrate.

These metaphors are ecologically destructive, as they are promoting excessive consumerism, also make the audience feel that if they consume a drink (Coulter et al., 2001). It can empower them, and they can take charge of their lives. Inspiration for success, supporting a child's mission for future goals, and having a tea partner are human attributes, but the companies have mapped them onto their products. Similarly, feeling good and spending time on an island is made equivalent to the consumption of products. Consumers are made to feel that they do not need to put much effort into it; they can attain them by purchasing products (Yanow, 2008). Moreover, through metonymy, humanly characteristics are given to the products or the companies, having some goals and desires, which provide them with authority to perform human beings' functions. By taking this authority, the companies can persuade the audience through their language and affect the audience's cognition while making choices in social acts.

\section{CONCLUSION}

The present research focused on the ecolinguistic analysis of metaphors in the advertisement. Based on the investigation, it can be said that metaphors, having a persuasive appeal, has a crucial role to play in advertising discourses. The products' manufacturers advertently use an analogy to grab the audience's attention towards their products and evaluate their products positively in the readers' minds through their association with positive qualities or traits of other entities. The kind of metaphors used in the advertisements does affect the feelings of the audience. Through the use of trigger words of the source domain, the audience frames the advertised product similarly in their minds. It affects their cognition, which in return affects their behavior. The audience may prefer to spend money on the products to experience those desirous feelings without any extra effort. These metaphors can be ecologically destructive because they discarded other human beings' value and nature and replaced it with human-made products.

\section{REFERENCES}

1. Ain, Q., Ahmed, F., \& Nawaz, M. (2021). An Ecolinguistic Analysis of Linguistic Discourses in Advertisements Frame Stories to Enhance their Importance to Replace Natural Products. Humanities \& Social Sciences Reviews, 9(2), 150-159. https://doi.org/10.18510/hssr.2021.9215

2. Alexander, R., \& Stibbe, A. (2014). From the analysis of ecological discourse to the ecological analysis of discourse. Language Sciences, 41, 104-110. https://doi.org/10.1016/j.langsci.2013.08.011

3. Bang, J. C., \& Trampe, W. (2014). Aspects of an ecological theory of language. Language Sciences, 41, 83-92. https://doi.org/10.1016/j.langsci.2013.08.009

4. Burgers, C., Konijn, E. A., Steen, G. J., \& Iepsma, M. A. (2015). Making ads less complex, yet more creative and persuasive: The effects of conventional metaphors and irony in print advertising. International Journal of Advertising, 34(3), 515-532. https://doi.org/10.1080/02650487.2014.996200

5. Caballero, R. (2003). Metaphor and genre: The presence and role of metaphor in the building review. Applied Linguistics, 24(2), 145-167. https://doi.org/10.1093/applin/24.2.145

6. Charteris-Black, J. (2009). Metaphor and political communication Metaphor and discourse (pp. 97-115): Palgrave Macmillan, London. https://doi.org/10.1057/9780230594647_7

7. Chen, S. (2016). Language and ecology: A content analysis of ecolinguistics as an emerging research field. Ampersand, 3(1), 108-116. https://doi.org/10.1016/j.amper.2016.06.002

8. Coulter, R. A., Zaltman, G., \& Coulter, K. S. (2001). Interpreting consumer perceptions of advertising: An application of the Zaltman Metaphor Elicitation Technique. Journal of Advertising, 30(4), 1-21. https://doi.org/10 $.1080 / 00913367.2001 .10673648$

9. Damico, J. S., Baildon, M., \& Panos, A. (2020). Climate Justice Literacy: Stories-We-Live-By, Ecolinguistics, and Classroom Practice. Journal of Adolescent \& Adult Literacy, 63(6), 683-691. https://doi.org/10.1002/jaal.1051

10. Delbaere, M., McQuarrie, E. F., \& Phillips, B. J. (2011). personification in advertising. Journal of Advertising, 40(1), 121-130. https://doi.org/10.2753/JOA0091-3367400108

11. DeRosia, E. D. (2008). The effectiveness of nonverbal symbolic signs and metaphors in advertisements: An experimental inquiry. Psychology \& Marketing, 25(3), 298-316. https://doi.org/10.1002/mar.20210

12. Ding, W. (2020). Natural Metaphor and Cognition in Virginia Woolf's Ecological Novels. Advances in Literary Study, 8(2), 46-57. https://doi.org/10.4236/als.2020.82005

13. Döring, M., Penz, H., \& Trampe, W. (2008). Language, Signs and Nature: Ecolinguistic Dimensions of Environmental Discourse: L: Stauffenburg Verlag.

14. Fill, A., \& Muhlhausler, P. (2006). Ecolinguistics reader: Language, ecology and environment: A\&C Black.

15. Forceville, C. (2000). Compasses, beauty queens and other PCs: Pictorial metaphors in computer advertisements. HERMES-Journal of Language and Communication in Business(24), 31-55. https://doi.org/10.7146/hjlcb.v13i $\underline{24.25568}$ 
16. Freeman, M. (2000). Poetry and the scope of metaphor: Toward a cognitive theory of literature. Metaphor and Metonymy at the Crossroads: A cognitive perspective, 30, 253. https://doi.org/10.1515/9783110894677.253

17. Grant, C. (2012). Analogies and links between cultural and biological diversity. Journal of Cultural Heritage Management and Sustainable Development, 2(2), 153-163. https://doi.org/10.1108/20441261211273644

18. Hampe, B. (2017). Metaphor: Embodied cognition and discourse: Cambridge University Press. https://doi.org/10.1017/9781108182324

19. Harnendaz, F. J. R. M. I. L. P. (2011). The Contemporary Theory of Metaphor: Myths, Developments and Challenges. Metaphor and Symbol, 26(3), 161-185. https://doi.org/10.1080/10926488.2011.583189

20. Hasyim, M. (2017). The metaphor of consumerism. Journal of Language Teaching and Research, 8(3), 523-530. https://doi.org/10.17507/jitr.0803.10

21. Jensen, D. (2006). Metaphors as a bridge to understanding educational and social contexts. International Journal of Qualitative Methods, 5(1), 36-54. https://doi.org/10.1177/160940690600500104

22. Kao, T.-F., \& Du, Y.-Z. (2020). A study on the influence of green advertising design and environmental emotion on advertising effect. Journal of cleaner production, 242, 118294. https://doi.org/10.1016/j.jclepro.2019.118294

23. Kovecses, Z. (2017). Conceptual Metaphor Theory. In Z. D. Elena Semino (Ed.), The Routledge Handbook of Metaphor and Language (pp. 16). UK.

24. Kraljevic-Mujic, L. H.-D. a. B. (2017). Metaphor and persuasion in commercial advertising. In E. S. a. Z. Demjin (Ed.), The Routledge Handbook of Metaphor and Language. UK: Routledge.

25. Kravchenko, A. V. (2016). Two views on language ecology and ecolinguistics. Language Sciences, 54, 102-113. https://doi.org/10.1016/j.langsci.2015.12.002

26. Lakoff, G., \& Johnson, M. (2008). Metaphors we live by: University of Chicago press.

27. Liu, Y., Li, K., Li, L., Zhang, J., Lin, Y., DiFabrizio, B., \& Wang, H. (2020). Morphological Metaphor Mapping of Moral Concepts in Chinese Culture. Frontiers in Psychology, 11. https://doi.org/10.3389/fpsyg.2020.554061

28. Martin, B., \& Simintiras, A. C. (1995). The impact of green product lines on the environment: does what they know affect how they feel? Marketing Intelligence \& Planning. https://doi.org/10.1108/02634509510088991

29. McQuarrie, E. F., \& Phillips, B. J. (2005). Indirect persuasion in advertising: How consumers process metaphors presented in pictures and words. Journal of Advertising, 34(2), 7-20. https://doi.org/10.1080/0091336 7.2005.10639188

30. Mohammed, S. F. (2020). Symbolic metaphor in commercial advertisements designs. journal of the college of basic education, 26(109/s).

31. Morgan, S. E., \& Reichert, T. (1999). The message is in the metaphor: Assessing the comprehension of metaphors in advertisements. Journal of Advertising, 28(4), 1-12. https://doi.org/10.1080/00913367.1999.10673592

32. Musolff, A. (2012). The study of metaphor as part of critical discourse analysis. Critical discourse studies, 9(3), 301-310. https://doi.org/10.1080/17405904.2012.688300

33. Nahak, M. M. N., Simpen, I. W., Yadnya, I. B. P., \& Satyawati, N. M. S. (2019). Lexicon in Batar Text: Ecolinguistics View. International Journal of Linguistics, Literature and Culture, 5(6), 48-59. https://doi.org/10.21744/ijllc.v5n6.763

34. Norton, C., \& Hulme, M. (2019). Telling one story, or many? An ecolinguistic analysis of climate change stories in UK national newspaper editorials. Geoforum, 104, 114-136. https://doi.org/10.1016/j.geoforum.2019.01.017

35. Nuzwaty, A. M. M., Setia, E., \& Zein, T. T. (2014). Metaphorical Expression of Bahasa Aceh in Trumon of South Aceh: Ecolinguistics Study. IOSR Journal Of Humanities And Social Science (IOSR-JHSS) Volume, 19, 32-37. https://doi.org/10.9790/0837-191133237

36. Qiushi, L. (2020). A Corpus-based Analysis of Multimodal Metaphor in Chinese Ecological Educational Advertisements. International Journal of Language and Linguistics, 8(2), 60. https://doi.org/10.11648/j.ijll.2 0200802.11

37. Rai, N. (2013). Impact of Advertising on Consumer behaviour and attitude with reference to consumer durables. International Journal of Management Research, 2(2), 74-79.

38. Semino, E., \& Demjén, Z. (2016). The Routledge handbook of metaphor and language: Taylor \& Francis. https://doi.org/10.4324/9781315672953

39. Sopory, P., \& Dillard, J. P. (2002). The persuasive effects of metaphor: A meta-analysis. Human communication research, 28(3), 382-419. https://doi.org/10.1111/j.1468-2958.2002.tb00813.x

40. Stibbe, A. (2014). An ecolinguistic approach to critical discourse studies. Critical discourse studies, 11(1), 117-128.

41. Stibbe, A. (2015). Ecolinguistics: Language, ecology and the stories we live by: Routledge. https://doi.org/10.1080/17405904.2013.845789

42. Stoyanova, E. V. (2021). Metaphor as a means of creating a humorous effect in Bulgarian media texts. The European Journal of Humour Research, 9(1). https://doi.org/10.7592/EJHR2021.9.1.Stoyanova 
43. Thibodeau, P. H., Matlock, T., \& Flusberg, S. (2019). The role of metaphor in communication and thought. 13(5), e12327. https://doi.org/10.1111/lnc3.12327

44. Yanow, D. (2008). Cognition meets action: Metaphors as models of and models for. Political language and metaphor, 225-238.

45. Yuniawan, T. (2018). Ecolinguistic study of conservation news texts in Indonesian mass media. International Journal of Humanity Studies (IJHS), 1(2), 163-183. https://doi.org/10.24071/ijhs.2018.010203 